\title{
The effect of service marketing mix elements and customer retention towards clothing store brands in China
}

DOI: 10.35530/IT.072.04.1777

BESTOON OTHMAN

WIRYA NAJM RASHID

HE WEIJUN

JING XI

ZHENGWEI HUANG

FANG YUAN

\begin{abstract}
REZUMAT
The effect of service marketing mix elements and customer retention towards clothing store brands in China

The aim of this paper was to analyse the impact of service marketing mix (promotion, price, place, product, people, process, physical evidence and after sale service) on customer retention towards clothing store brands in China. Based on the analysis of past literature, it appeared that there were only few studies examining the empirical relation between the two constructs, particularly in the clothing sector in China. A comprehensive survey approach was used to collect data from a total of 385 customers visiting clothing stores in the middle part of China (Hubei). SPSS and PLS were used to analyse the obtained data. The findings showed that there were significant positive effects on customer retention in all dimensions of the service marketing mix. Finally, the findings suggested that after-sales service plays an important role in impacting the retention of customers. The contribution of this research was supporting the significance relationship of the marketing mix elements in influencing the retention of customers in the clothing industry with empirical data from China.
\end{abstract}

Keywords: product, after sale service, price, physical evidence, process, clothing industry

Influența elementelor mix de marketing pentru servicii și fidelizarea clienților față de mărcile magazinelor de îmbrăcăminte din China

Scopul acestei lucrări a fost de a analiza impactul mixului de marketing al serviciilor (promovare, preț, locație, produs, persoane, proces, dovezi fizice și servicii post-vânzare) asupra fidelizării clienților față de mărcile magazinelor de îmbrăcăminte din China. Pe baza analizei literaturii de specialitate, s-a constatat că au existat puține studii care să analizeze relația empirică dintre cele două concepte, în special în sectorul îmbrăcămintei din China. O abordare cuprinzătoare a sondajului a fost utilizată pentru a colecta date de la un total de 385 de clienți, care vizitează magazinele de îmbrăcăminte din partea de mijloc a Chinei (Hubei). SPSS și PLS au fost utilizate pentru a analiza datele obținute. Rezultatele au arătat că au existat influențe pozitive semnificative asupra fidelizării clienților în toate dimensiunile mixului de marketing al serviciilor. În cele din urmă, rezultatele au sugerat că serviciul post-vânzare joacă un rol important asupra fidelizării clienților. Contribuția acestei cercetări a susținut relația de semnificație a elementelor mix de marketing în influențarea fidelizării clienților din industria de îmbrăcăminte cu date empirice din China.

Cuvinte cheie: produs, serviciu post-vânzare, preț, dovezi fizice, proces, industria de îmbrăcăminte

\section{INTRODUCTION}

Customer retention is one of the most important advertising issues that has gained tremendous attention from many academics and business practitioners. Maintaining consumers is seen as an important goal in today's highly competitive market environments for several business organizations [1]. Many companies use their time and financial expenses extensively to establish long-lasting and beneficial relationships with potential and existing customers to enhance their performance in the marketplace [2]. Past research has shown that focusing on customer retention has been widely regarded as the most important goal for companies implementing marketing relationship strategy $[3,4]$. While customer retention can be conceptualized and calculated differently from industry to others [5], a number of scholars conclude that the focus on customer retention can contribute to various financial benefits [6]. Therefore, designing and executing a marketing partnership strategy to retain business customers will allow companies to achieve competitive advantages that are sustainable [2].

Retention of customers has now become a very important marketing strategy, particularly in the clothing industry. This is because the clothing industry has experienced steady growth over the past couple of years as new clothing trends have emerged from the traditional markets through the growth of supermarket philosophy allowing the diversity of retail consumers in different parts of the world pleasure and distinctive shopping experience [7]. Shopping has 
recently become an interesting experience for consumers that can ensure their satisfaction and decrease their stresses as they are introduced under one roof to different brands and product categories where options are respected and handled with expertise and friendliness [8]. Recent research has shown that consumer retention in the clothing sector can be affected by numerous marketing factors such as promotion, price, place, product, people, process, physical evidence and after sale service. This is because in order to deliver consumer loyalty and satisfaction, these factors are considered essential [8].

There are some gaps in this area despite the increased importance in customer retention research. According to Zhengwei [9], over the past decades, customer retention has been widely accepted as an important topic, but there is limited research focusing on management processes associated with customer retention performance. In addition, various studies on customer retention and its key antecedents have been conducted in the developed countries.

Nevertheless, there are only a few studies that have been carried out in the developing world on customer retention. This study is planned to examine the impact of selected marketing mix elements on customer retention in the clothing industry based on the identified gaps. The findings would have beneficial implications for clothing industry decision-makers. For this study, the following section presents the literature review and the methodology and findings followed. After that, the last sections explain the discussion of the findings and conclusion.

\section{LITERATURE REVIEW AND HYPOTHESES DEVELOPMENT}

\section{Customer retention}

Undoubtedly, customer retention is considered one of the key goals for marketing partnerships. For several organizations, the emphasis on customer retention has been significantly appreciated in the current business environment. Therefore, it is important to empirically analyse the predictors of customer retention in order to effectively apply the advertising principles [6]. Some scholars Kofi et al [5] and Chen and Liu [1] viewed customer retention as an element of customer loyalty, whereas Han and Hyun [10] regarded retention as an effort to maintain a continuous partnership with a particular organization. The concept of customer retention refers to a customer's desire, belief, attachment, and dedication to a product and ability to recommend it to others. In other words, customer retention refers to the process that loyally produces the customer towards a certain product that can be expressed by repurchase behaviour [10]. Hanaysha [2] also claimed that customer retention occurs if a customer continues to buy a brand's products or services over a long period of time.

Furthermore, retention of customers suggests that a lasting relationship between a company and its customers can bring economic benefits for both parties [11].
When looking at past research, it indicates that customer retention has several advantages, such as superior business growth and higher profit margins [6]. For fact, customer retention can save the company a lot of money as the cost of getting new customers usually exceeds the cost of keeping current customers numerous times. Many researchers have also revealed that long-term consumers are likely to buy more, attract new customers, take less time from service providers, and be less prone to price changes [1,12]. In addition, Eid [3] estimated that attracting new customers would cost seven times more than mainstreaming existing customers, and thus concentrating on customer retention could increase organizational income. It ensures that lifelong consumers are likely to have a higher level of satisfaction and, among others, will spread positive word of mouth [5]. Nonetheless, companies should provide outstanding services to their customers and manage any grievances from them effectively to improve the creation process of customer retention [10]. Han and Hyun [10] also pointed out that in order to maintain clients, service providers must make greater efforts to build the relationships of personal customers that may contribute to their loyalty to the company.

\section{Relationship between service marketing mix and customer retention}

Puluhulawa et al. [13] found that the marketing mix consists of a set of different marketing tools that companies can use to achieve their marketing objectives. The marketing decision factors in different marketing mix models offer input and advice to business plans that prioritize marketing tactics [14]. Marketing mix points out the key tasks that marketing managers will pursue. Once a target market has been established, marketing managers are then responsible for developing a marketing plan to sell their products/services to customers and create lasting relationships with them. Marketing plan involves important product, location, price and marketing decisions that are considered to be the most important aspects that include an efficient allocation of organizational resources in order to maximize sales and profit margins [15]. Similarly, seven marketing mix elements were incorporated in modern marketing practices by Yaghoubian et al. [16], which included product, place, promotion, price, process, people, and physical evidence. Some researchers added additional marketing mix elements such as variable building after-sales service. This study combines eight elements for calculating marketing mix in the clothing industry; promotion, price, place, product, people, process, physical evidence and after sale service. Based on several past studies coupled with conceptualization of a contemporary idea, this study suggests the following hypothesis:

H1: The service marketing mix has a positive effect on the customer retention.

The relationship between product and customer retention 
It is MM's first and foremost component and heart, as long as there is no product or service, other SMM components lose their significance. In this respect, it should be attempted by visible mechanisms to mark the facilities as measurable [17]. In order to define a product, the concept of Jobhaarbima, [18] is used whereby "a product is anything that can be sold to a market for interest, acquisition, use or consumption that may fulfil a desire or need" [19]. Therefore, when designing a product/service, it is important that a customer's perspective should be given to the package of benefits in the service offer [20]. Hence, we propose the hypothesis of the study as follows:

H1a: The clothes product has a positive effect on the customer retention.

The relationship between promotion and customer retention

Promotion is considered to be a key marketing factor influencing consumer behaviour. Some researchers Shukor [21] have defined advertisement as a form of communication between a company and its consumers that is specifically designed to promote certain products and services. Nonetheless, advertising managers ' ability to create brand awareness of their products/services and convince or discourage potential customers to make buying offers depends on several factors in most situations, such as convenience, cost equality, as well as the effectiveness of promotional campaigns. The success of marketing campaigns depends on advertisers ' willingness and ability to clearly identify their target customers. Organizations spend a lot of money on research to be able to identify the features of their target audience, then develop the correct marketing campaigns and choose the most important outlets to convey the advantages of their products and services to potential clients. Advertising strategies are therefore aimed at shaping the reactions of customers to a brand's marketing activities and establishing successful relationships with them. Therefore the following hypothesis has been proposed:

H1b: The clothes promotion has a positive effect on the customer retention.

The relationship between price and customer retention

Price was also considered to be a crucial marketing tool for consumer purchases of a product or service [22]. Previously, the concept of price was defined in the literature as the monetary value of a product or service [23]. In other words, price is the financial value given to a commodity that includes both its cost and the expected income. Puluhulawa et al. [13] found that customers who are likely to be price sensitive tend to avoid buying from products selling at higher prices and not taking the interests of consumers at hand. Other scholars Aras et al. [24] have observed that when customers tend to make purchase decisions, they look at the price initially and give it high credit relative to other attributes. Similarly, Hiransomboon [25] reported that a particular service provider's product repurchase decisions rely on their previous purchasing experience in terms of value for money. Price was considered an important determinant of customer retention and satisfaction for this reason. Based on the following hypothesis, therefore, we can assume to test the relationship:

H1c: The clothes price has a positive effect on the customer retention.

The relationship between place and customer retention

Place or location is an essential marketing mix factor that can be described as where a company wants to sell their products or services to specific market segments in order to make them easily accessible. Thamrin [26] explained that place is the management judgements as to where the products or services are to be distributed to consumers, and may consist of digital or physical distribution channels. In addition, Octavia [27] has stated its stance as any way that consumers may access a certain brand's product or service. Obviously, a successful decision on the channel needs businesses to have clear knowledge of their target markets [20]. The location of the shop is considered the most important factor for business success and customer retention in the clothing industry. Location convenience plays a key role in shaping the choices made by the consumer about the services provided by the shop. Finally, by making the right decision to locate an intermediary's store for selling its products and services, a good place seems to be meeting the needs of consumers. Hence, the following hypothesis could be proposed:

H1d: The clothes place has a positive effect on the customer retention.

The relationship between people and customer retention

Considering the coexisting availability of facilities and the interaction between provider and servant, the importance of workers in the facility is fundamental and critical accuracy needs to be committed to the factors of staff-related recruitment, training, encouragement and other human resources [27]. It is important to observe the importance of employers in an organization with a focus on staff development. In Clothing Store Brands, the element of people is crucial and has an essential characteristic to influence branding and customer retention. On the other hand, there are a number of brand clothes that implement brand clothing technology. For example, another phase requires the appearance of service staff and travel agent services to be more professional and involve more methodological skills. Therefore, this hypothesis is proposed:

H1e: The clothes people have a positive effect on the customer retention.

The relationship between process and customer retention

The product management and marketing process has an influence on service quality. Possibilities, constraints and conditions of supply and demand are important factors that influence the service provision system. The simplicity of the service system is compatible with the comfort and satisfaction of consumers in terms of quick and easy delivery [28]. 
Somocor [23] defined the process as the procedures, mechanisms and activities needed to deliver services. Clothing Store Brands is generally considered to be a standard and unchangeable service location. Thus, we propose the following hypothesis:

H1f: The clothes process has a positive effect on the customer retention.

The relationship between Physical evidence and customer retention

In order to deliver programs and realize potential services, diversity of physical, material tools and facilities as elements of service organization are essential.

Customer retention is associated with up-to-date and more analytical services [28]. Clothing store brands could generally be considered a typical procedure, and the location of the service is unchangeable. Implementing brand clothing technology in services is a key element in reducing reliance on the human aspect and advancing for clothing store brands. Using software in clothing store brands helps provide day-to-day (twenty-four hour operation), time and transaction reliability, improved monitoring of clothing store brands, and online application assistance. Clothing store brands can be considered a place for cloth customers to learn, wear, and experience clothing store brands. Clothing store brands plays a major role in delivering facilities as a non-transferable central authority, so consumers can enjoy the facilities as clothing-style services. Appropriate delivery of physical evidence in clothing store brands therefore has a positive impact on customer experience and enjoyment during product use, including: processes, paperwork, office environment, and equipment. Thus, the following assumption has been stated:

H1g: The clothes physical evidence has a positive effect on the customer retention.

The relationship between after sale service and customer retention

Lastly, after sales service has changed market practices due to rapid technological advancement, intense demand, and increased profits [29]. Now, the after-sales service has shifted from a cost center to a major source of profit, reaching up to $45 \%$ of revenue in many businesses [30]. Service providers' aftersales service policy is influenced by specific terms such as service contracts, warranty, consumer characteristics and brand characteristics [29]. After sale service ensure that consumers' loyalty is fulfilled with the products they have provided. Of example, for both parties, the sale of tickets to consumers during holidays is not necessarily the completion of the selling business. Clothing store brands have to inquire about their satisfaction for after sale services from customers after the purchase. This will create a good image of clothing store brands and demonstrate genuine concerns about customer relationships [31]. Therefore, the following hypothesis has been proposed:

H1h: The clothes after sale service have a positive effect on the customer retention.

Based on the above literature, figure 1 shows details of the proposed study of this paper.

This study used the approach of quantitative research to gather data from respondents. For this study, the target population consisted of clothing store brands customers in China. The data was collected using a survey method from 267 customers in the specified part of China who have real experience buying clothing store brands shop. The survey tool enables response from large numbers of individuals to be collected at minimal cost and within a shorter period of time relative to other forms of data collection. The minimum sample size to analyse data using structural equation modelling (SEM) should be 200 [32]. The sample used in this study is therefore considered sufficient to use Smart PLS to analyse the data. After developing the questionnaire based on previous studies, the data collection process was initiated. Customer retention was assessed by adapting and adjusting a scale of four items from the [33]. Likewise, from previous studies, the measurement levels of the chosen service marketing mix have been modified. For example, product was calculated using Shareef et al. [34] to adapt four products. Four items have also been developed to measure the price based on previous research and literature. Also developed were the four items for measuring promotion based on the measurement scale used by [35]. In addition, place was measured using Shareef et al. [34] to adapt five items. The four items for measuring people were also developed on the basis of Ling's [35] measurement scale. Process was measured using four items from the Ling study [35].

Additionally, a five items scale was adapted from Yoo et al. [36] to measure physical evidence. Finally, after sale service was measured using five items being 
taken from the study of [35]. All items are measured on a Likert scale of five scales, ranging from strongly disagree to strongly agree.

\section{ANALYSIS OF RESULTS}

\section{Profile of respondents}

The quantitative analysis showed that $44.6 \%$ of the participants are male, while $55.4 \%$ are women. The research also showed that a degree credential was accessible to most participants. In terms of monthly income, an average income of 67 respondents was below $600 \$$, defined by $25.1 \%$, and an average income of 43 participants $(16.1 \%)$ ranged from $601 \$$ to $1000 \$$. There are also 75 respondents whose monthly income ranged from $1001 \$$ to $1500 \$$ and accounted for $28.1 \%$, and finally, 82 respondents $(30.7 \%)$ had a monthly income of more than $15001 \$$.

\section{Assessment of measurement model}

Table 1 describes the analysis of this study's build reliability and convergent reliability. As illustrated, the reliability of the composite for customer retention is 0.900 , the product dimension is 0.940 , while the service dimension after sale is 0.959 . All of the above Composite Quality values indicate the internal consistency of the constructs. Essentially, the quality of Cronbach's alpha and composite is similarly perceived [37, 38]. Prior research indicates that the threshold level of 0.60 or higher is needed in exploratory research to demonstrate adequate composite reliability, but not to exceed 0.95 [37].

The next step is to observe the accuracy of the metrics where the analysis is to determine the degree to which a factor or group of variables is consistent with what it aims to calculate [39]. Sarstedt et al. [37] proposed that the charging of the indicator must exceed 0.7 . Accordingly, the indicator reliability values ranged from 0.851 to 0.946 , which surpassed the minimum value of 0.7 , can be seen in table 1 . The results obtained from this stage provide a significant indication that these buildings provide an adequate convergent validity resulting in no removal of objects based on low loads. In addition, the measurement template analysis also shows that all the AVE values of the build are above 0.7 . The result shows that the study's AVE exceeded the minimum value 0.5 of the derived average variance (AVE) indicating that the items loaded into the respective constructs explain more than $50 \%$ of the variance of the constructs [40]. In addition to the measurement model analysis, Fornell and Larcker [41] were performed to test the discriminating validity. Table 2 indicates the criteria of Fornell and Larcker. The results from this study show that for every construct the square root of AVE is greater than the construct's correlation estimate. Therefore, it is noted that the concepts contrast with each other according to the discriminating validity criterion of [41].

\section{Hypothesis}

In this subheading, analysis on the direct effects hypotheses between latent constructs has been made through PLS-SEM algorithm and bootstrapping of 5,000 subsamples iterations. The direct effect hypotheses are the hypotheses that predict direct connection to a latent construct with another as indicated by an arrow. The present study has eight direct effect hypotheses coded as $\mathrm{H} 1 \mathrm{a}, \mathrm{H} 1 \mathrm{~b}, \mathrm{H} 1 \mathrm{c}, \mathrm{H} 1 \mathrm{~d}$, $\mathrm{H} 1 \mathrm{e}, \mathrm{H} 1 \mathrm{f}, \mathrm{H} 1 \mathrm{~g}$ and $\mathrm{H} 1 \mathrm{~h}$ for testing. Table 3 shows the results of the direct effect of the hypothesis test. In testing the hypotheses, the path standardised estimate or beta $(\beta)$, standard errors (S.E.), t-value and probability value were used and thus, presented in a parenthesis and also in diagram [40]. Suggestion by Chin [37], the $\beta$ value of standardized paths should be around 0.20 but more ideally, the value has to be above 0.30 to be considered as meaningful. In the five direct effects, hypotheses of the study are discussed.

The data analysis results show that SMM positively and significantly affects the total sample CR $(\beta=0.828, p=0.000)$ in support of Hypothesis 1 . The data results also show that the dimension of the after-sale service has a positive and significant impact on the total sample CR (Beta $=0.137$, $p=0.000)$. Hence, the proof is sufficient to support all the study hypotheses. It is therefore assumed that the CR is greatly and positively influenced by SMM and its measurements.

According to Hair [40], the primary assessment criterion of the structural model by PLS-SEM is the $\mathrm{R}^{2}$ measures and to determine the significance level of the path coefficients. The reason is because the objective of the prediction-oriented PLSSEM approach is to explain the variance of endogenous latent variable and reasonably high $\mathrm{R}^{2}$ value should be obtained. A rule of thumb in marketing research studies, $R^{2}$ values of $0.75,0.50$, or 0.25 for endogenous latent variables in the structural model can be represented as substantial, moderate, or weak, respectively. Accordingly, the obtained $\mathrm{R}^{2}$ value can be used to interpret the quality of the structural model which indicates the explanatory variance by the exogenous variables contained in the endogenous variable. Assessment results it can be explained the $\mathrm{R}^{2}$ was found to be 0.686 for $C R$, indicating that SMM can account for $68.6 \%$ of the variance in the $C R$, which was substantial level (figure 2).

\section{Discussions}

The idea is that the service marketing mix has a favourable and significant effect on customer retention, as can be seen in table 1, the findings show that SMM has a significant effect on customer retention $(\beta=0.828, \mathrm{t}$-value $=36.743, p=0.000)$, so $\mathrm{H} 1$ is acknowledged. The findings of all sub-hypothesis testing indicate that the service marketing mix have a significant positive impact on the retention of customers. Factor contributing to the positive impact and significant marketing mix on customer retention, 


\begin{tabular}{|c|c|c|c|c|c|}
\hline \multicolumn{6}{|c|}{ INTERNAL CONSISTENCY AND CONVERGENT VALIDITY } \\
\hline Parameters & Cronbach's Alpha & Items & Factor loading & $\begin{array}{c}\text { Composite } \\
\text { reliability }\end{array}$ & $\begin{array}{l}\text { Average Variance } \\
\text { Extracted (AVE) }\end{array}$ \\
\hline \multirow{5}{*}{ After sale service } & \multirow{5}{*}{0.946} & AFSS1 & 0.923 & \multirow{5}{*}{0.959} & \multirow{5}{*}{0.824} \\
\hline & & AFSS2 & 0.916 & & \\
\hline & & AFSS3 & 0.932 & & \\
\hline & & AFSS4 & 0.884 & & \\
\hline & & AFSS5 & 0.884 & & \\
\hline \multirow{4}{*}{ Customer retention } & \multirow{4}{*}{0.851} & CR1 & 0.777 & \multirow{4}{*}{0.900} & \multirow{4}{*}{0.692} \\
\hline & & CR2 & 0.839 & & \\
\hline & & CR3 & 0.873 & & \\
\hline & & CR4 & 0.836 & & \\
\hline \multirow{4}{*}{ People } & \multirow{4}{*}{0.942} & PEP1 & 0.923 & \multirow{4}{*}{0.958} & \multirow{4}{*}{0.852} \\
\hline & & PEP2 & 0.927 & & \\
\hline & & PEP3 & 0.929 & & \\
\hline & & PEP4 & 0.913 & & \\
\hline \multirow{5}{*}{ Physical evidence } & \multirow{5}{*}{0.944} & PHY1 & 0.906 & \multirow{5}{*}{0.957} & \multirow{5}{*}{0.818} \\
\hline & & PHY2 & 0.911 & & \\
\hline & & PHY3 & 0.904 & & \\
\hline & & PHY4 & 0.907 & & \\
\hline & & PHY5 & 0.893 & & \\
\hline \multirow{5}{*}{ Place } & \multirow{5}{*}{0.928} & PLC1 & 0.872 & \multirow{5}{*}{0.946} & \multirow{5}{*}{0.778} \\
\hline & & PLC2 & 0.908 & & \\
\hline & & PLC3 & 0.905 & & \\
\hline & & PLC4 & 0.840 & & \\
\hline & & PLC5 & 0.883 & & \\
\hline \multirow{4}{*}{ Price } & \multirow{4}{*}{0.917} & PRC1 & 0.914 & \multirow{4}{*}{0.942} & \multirow{4}{*}{0.802} \\
\hline & & PRC2 & 0.905 & & \\
\hline & & PRC3 & 0.874 & & \\
\hline & & PRC4 & 0.888 & & \\
\hline \multirow{4}{*}{ Process } & & PRO1 & 0.916 & & \\
\hline & 0905 & $\mathrm{PRO} 2$ & 0.892 & 0.031 & 780 \\
\hline & 0.905 & PRO3 & 0.915 & 0.904 & 0.100 \\
\hline & & $\mathrm{PRO} 4$ & 0.805 & & \\
\hline & & PRD1 & 0.871 & & \\
\hline & & PRD2 & 0.922 & & \\
\hline Product & 0.915 & PRD3 & 0.886 & 0.940 & 0.797 \\
\hline & & PRD4 & 0.891 & & \\
\hline & & PRM1 & 0.870 & & \\
\hline Prometion & 076 & PRM1 & 0.871 & 015 & 730 \\
\hline Promotion & $0.8 / 6$ & PRM1 & 0.868 & 0.915 & 0.730 \\
\hline & & PRM1 & 0.807 & & \\
\hline
\end{tabular}

based on the results of the focus group known causes of the positive and significant effect of the service marketing mix on customer retention, believed by customers that product is a quality cloth, provide competitive prices, good sales media communications, easily accessible dealer showroom, customersensitive staff and ample facilities and services available to cause high customer retention. The claim clarified that it is not possible to achieve the development of customer retention by a single dimension, but the entire dimension inherent in the marketing mix. In addition to the several areas of consumer buying behaviour in China, due to cultural factors, the result is customer retention. That in some tribes/communities in China they have a habit and conviction that it's a brand fabric, if not clothing store brands, 


\begin{tabular}{|l|c|c|c|c|c|c|c|c|c|}
\hline \multicolumn{7}{|c|}{ FORNELL AND LARCKER CRITERION } \\
\hline Parameters & $\begin{array}{c}\text { After sale } \\
\text { service }\end{array}$ & $\begin{array}{c}\text { Customer } \\
\text { retention }\end{array}$ & People & $\begin{array}{c}\text { Physical } \\
\text { evidence }\end{array}$ & Place & Price & Process & Product & Promotion \\
\hline After sale service & 0.908 & & & & & & & & \\
\hline Customer retention & 0.797 & 0.832 & & & & & & & \\
\hline People & 0.848 & 0.751 & 0.923 & & & & & & \\
\hline Physical evidence & 0.875 & 0.807 & 0.834 & 0.904 & & & & & \\
\hline Place & 0.817 & 0.749 & 0.811 & 0.828 & 0.882 & & & & \\
\hline Price & 0.749 & 0.712 & 0.735 & 0.807 & 0.784 & 0.895 & & & \\
\hline Process & 0.882 & 0.800 & 0.861 & 0.906 & 0.827 & 0.809 & 0.883 & & \\
\hline Product & 0.776 & 0.690 & 0.745 & 0.798 & 0.774 & 0.814 & 0.860 & 0.893 & \\
\hline Promotion & 0.811 & 0.739 & 0.801 & 0.842 & 0.839 & 0.816 & 0.841 & 0.800 & 0.854 \\
\hline
\end{tabular}

Table 3

\begin{tabular}{|c|c|c|c|c|c|}
\hline \multicolumn{7}{|c|}{ RESULTS OF HYPOTHESES } \\
\hline Hypotheses & Path & $\boldsymbol{\beta}$ & S.E & t-value & P Values \\
\hline $\mathrm{H} 1$ & $\mathrm{SMM} \rightarrow \mathrm{CR}$ & 0.828 & 0.023 & 36.743 & 0.000 \\
\hline $\mathrm{H} 1 \mathrm{a}$ & $\mathrm{AFSS} \rightarrow \mathrm{CR}$ & 0.137 & 0.004 & 33.013 & 0.000 \\
\hline $\mathrm{H} 1 \mathrm{~b}$ & $\mathrm{PEP} \rightarrow \mathrm{CR}$ & 0.108 & 0.003 & 33.128 & 0.000 \\
\hline $\mathrm{H} 1 \mathrm{c}$ & $\mathrm{PHY} \rightarrow \mathrm{CR}$ & 0.138 & 0.004 & 33.143 & 0.000 \\
\hline $\mathrm{H} 1 \mathrm{~d}$ & $\mathrm{PLC} \rightarrow \mathrm{CR}$ & 0.125 & 0.004 & 28.528 & 0.000 \\
\hline $\mathrm{H} 1 \mathrm{e}$ & $\mathrm{PRC} \rightarrow \mathrm{CR}$ & 0.099 & 0.004 & 26.207 & 0.000 \\
\hline $\mathrm{H} 1 \mathrm{f}$ & $\mathrm{PRO} \rightarrow \mathrm{CR}$ & 0.105 & 0.003 & 33.574 & 0.000 \\
\hline $\mathrm{H} 1 \mathrm{~g}$ & $\mathrm{PRD} \rightarrow \mathrm{CR}$ & 0.096 & 0.004 & 26.051 & 0.000 \\
\hline $\mathrm{H} 1 \mathrm{~h}$ & $\mathrm{PRM} \rightarrow \mathrm{CR}$ & 0.093 & 0.003 & 28.523 & 0.000 \\
\hline
\end{tabular}

Note: $\mathrm{AFSS}=$ after sale service; $\mathrm{PEP}=$ people $; \mathrm{PHY}=$ physical evidence; $\mathrm{PLC}=$ place $; \mathrm{PRC}=$ price$; \mathrm{PRO}=$ process $; \mathrm{PDT}=$ product; $\mathrm{PRM}=$ promotion; $\mathrm{SMM}=$ service marketing mix; $\mathrm{CR}=$ customer retention .

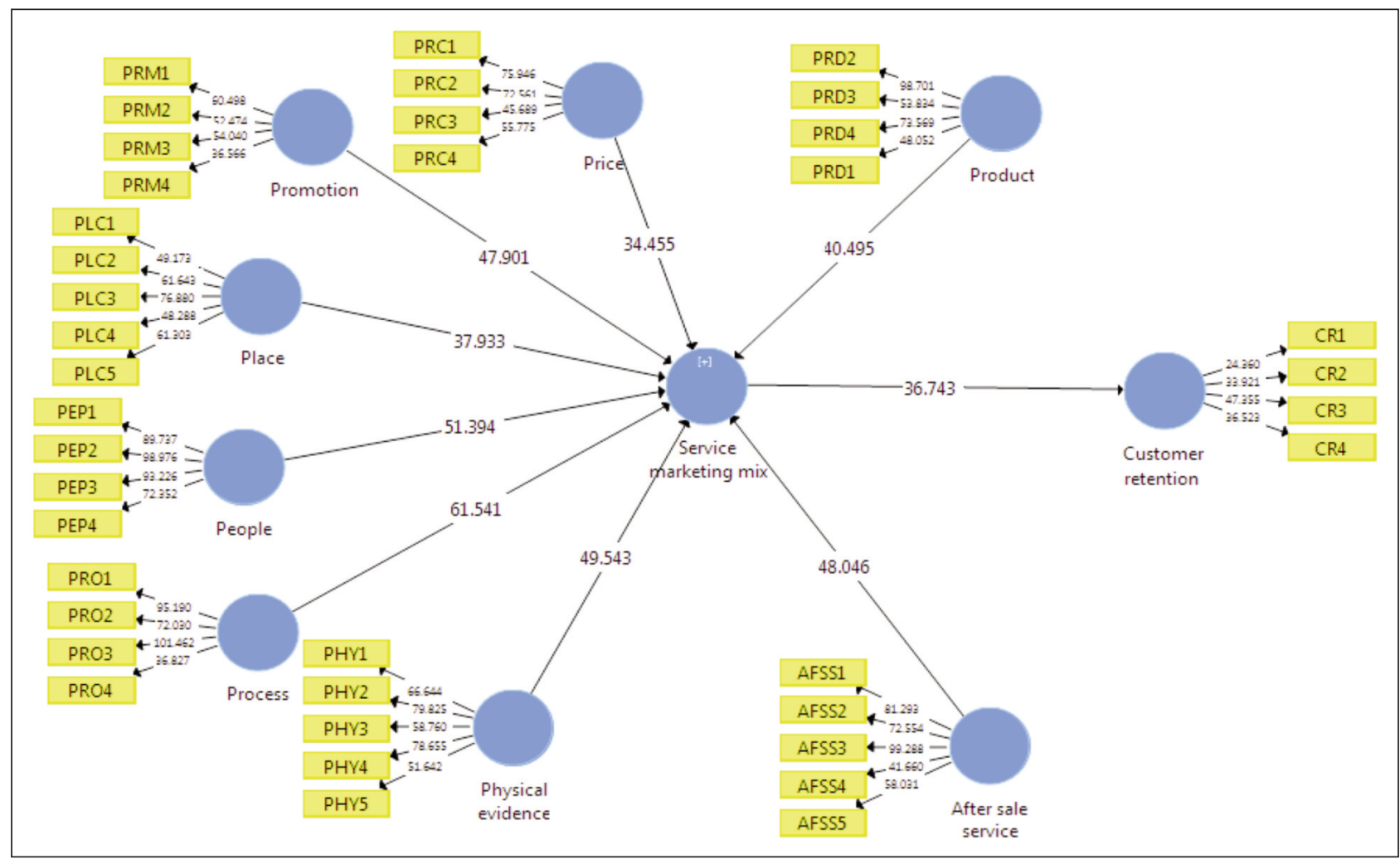

Fig. 2. PLS model path coefficient (bootstrapping at 500 resampling) 
they don't look at it as a product, and consumers will still make purchase decisions by buying clothes for whatever reason.

Cultural factors influence consumer behaviour as far as possible and as far as possible. Marketing needs to know the role of communities, subcultures, and groups in society. Culture refers to the idea as members of society, symbols that have meaning to communicate, values, interpretation and evaluation. From the consumer's beliefs, views, and habits towards a product, culture can be seen. Higher product confidence and higher customer decision to purchase affect customer retention [19]. The results support the theory of assuming fidelity that assesses the customer's loyal or disloyal views of fidelity to buy back on a regular basis, always recommends reference to the experience of the services received to others and has shown a positive response to the services offered [42]. Support on previous researchers' results, targeting studies conducted $[21,43]$ that marketing mix elements (price, product, place and promotion) have a significant impact on customer retention. Then have a correlation with Han and Hyun [10], findings that the service has a significant effect on retention, whilst pricing, staffing and procedures have a negligible effect on retention of customers. This study supports the partial results Puluhulawa et al. [13] that there is no significant effect on customer retention on the product and price in the other dimensions of the place and promotion.

\section{CONCLUSION}

Customer retention is the fact that having conservation clients is of the utmost importance, and it is also crucial that the service marketing mix can really help the company provider understand what variables the consumer is searching for when purchasing clothing store brands apparel. The goal of this research effort is to observe the relation in clothing store brands between customer retention and service marketing mix. It is therefore very critical that the fashion industry's business suppliers have awareness of marketing needs, as well as attracting customers to clothing store brands, as well as concentrating on how to keep them loyal. However, this study aims to relate in literature to both theory and practice.

\section{LIMITATION}

This paper has some drawbacks that would offer future research opportunities. First, the study's main focus was on department stores and only customers concerned. Future studies can therefore broaden the scope and be carried out in different areas of the country by including department store workers to gain better insight into the important factors in the clothing industry. In addition, the data were collected using systematic questions through quantitative survey; therefore, future studies may use other study to validate the findings. Furthermore, this study examined only a service marketing mix of eight dimensions of independent variables; thus, future research may consider other factors that may affect customer retention in China's clothing industry, such as social media marketing and corporate social responsibility.

\section{ACKNOWLEDGEMENTS}

The paper was written under a grant from the National Natural Science Foundation of China (No. 71471102).

\section{REFERENCES}

[1] Chen, C.-M., Liu, H.-M., The moderating effect of competitive status on the relationship between customer satisfaction and retention, In: Total Quality Management \& Business Excellence, 2017, 33, 1-24

[2] Hanaysha, J.R., Customer retention and the mediating role of perceived value in retail industry, 2016, https://doi.org/10.1108/WJEMSD-06-2017-0035

[3] Eid, R., Integrating Muslim Customer Perceived Value, Satisfaction, Loyalty and Retention in the Tourism Industry: An empirical study, In: International Journal of Tourism Research, 2015, 17, 249-260

[4] Hanzaee, K.H., Mirvaisi, M., Customer Orientation of Service Employees: A Case Study of Iranian Islamic Banking (Based on COSE Model), In: International Journal of Marketing Studies, 2011, 3, 4, 130-146

[5] Kofi Nyarko, I., Agyeman-Duah, M.O., Asimah, V., Measuring Customer Loyalty Using Retention, Advocacy and Patronage as Key Denominators, In: International Journal of Scientific and Research Publications, 2016, 6, 2, 375-380

[6] Nsiah, R., The Effect of Service Quality on Customer Retention in the Banking Industry in Ghana: A Case Study of Asokore Rural Bank Limited, 2018, https://doi.org/10.2139/ssrn.2493709

[7] Sadq, Z.m., Othman, B., Khorsheed, R.K., The impact of tourism marketing in enhancing competitive capabilities, In: African Journal of Hospitality, Tourism and Leisure, 2019, 8, 5, 1-11

[8] Othman, B.A., Harun, A., Rashid, W.N., Nazeer, S., Kassim, W.M., Kadhim, K.G., The influences of service marketing mix on customer loyalty towards Umrah travel agents: Evidence from Malaysia, In: Management Science Letters, 2019, 6, 865-876, https://doi.org/10.5267/j.msl.2019.3.002

[9] Huang, Z., Pei, X., Xi, J., Othman, B., Ali, S., The Influence of Consumers' Perception on Perceived Value and Purchase Intention with respect to Regional Products Based on a C-A-B Model, In: Tekstilec, 2019, 62, 3, 219-228, https://doi.org/10.14502/Tekstilec2019.62.219-228

[10] Han, H., Hyun, S.S., Customer retention in the medical tourism industry: Impact of quality, satisfaction, trust, and price reasonableness, In: Tourism Management, 2015, 46, 20-29 
[11] Hanaysha, J.R., An Examination of Marketing Mix Elements and Customer Retention in Malaysian Retail Market, In: American Journal of Marketing Research, 2017, 3, 1, 1-7

[12] Chavan, M.J., Faizan, A., Factors Affecting On Customer Satisfaction in Retail Banking: An Empirical Study, In: International Journal of Business and Management Invention, 2013, 2, 1, 2319-8028

[13] Puluhulawa, S., Mallongi, S., Sufri, M., The Influence Of Marketing Mix, Culture And Quality Of Service To Customer Satisfaction Mediated Decision Of Selecting Sharia Bank In Gorontalo Province, In: International Journal of Scientific \& Technology Research, 2018, 7, 9, 148-160

[14] Othman, B.A, Nazeer, S., Issues and Challenges Faced by Malaysian Umrah Travel Agencies in Providing Excellent Marketing Mix Services to Umrah Pilgrims, In: Journal of Social Sciences Research, 2018, 611-618, https://doi.org/https://doi.org/10.32861/jssr.spi12.611.618

[15] Haryani, D., Damita, A.G.D., Harunb, A., Martinb, D., Jabbar B.O., What makes a non-Muslim purchase halal food in a Muslim country? An application of theory of planned behaviour, In: Management Science Letters, 2019, 9, 12, 2029-2038, https://doi.org/10.5267/j.msl.2019.7.003

[16] Yaghoubian, S., Jahani, M.A., Yazdani-Charati, J., Mahmoudi, G., The role of marketing mix (the 7 Ps) in patients' attitudes to Iranian hospitals based on their kind of ownership (case study in Iran), In: International Journal of Healthcare Management, 2018, 1-5, https://doi.org/10.1080/20479700.2018.1505226

[17] Al-Dmour, H., Al-Zu'bi, Z.M.F., Kakeesh, D., The Effect of Services Marketing Mix Elements on Customer-Based Brand Equity: An Empirical Study on Mobile Telecom Service Recipients in Jordan, In: International Journal of Business and Management, 2013, 8, 11, 13-26

[18] Jobhaarbima, M., Marketing Mix and Service Quality Effect on Customer Satisfaction and Loyalty of Toyota Cars, In; Journal of Research in Business and Management, 2017, 5, 2, 13-23

[19] Islam, M., Yang, Y.-F., Hu, Y.-J., Hsu, C.-S., Marketing mix, service quality and loyalty—in perspective of customercentric view of balanced scorecard approach, In: Accounting, Accountability \& Performance, 2013, 18, 1, 1-17

[20] Kushwaha, G.S., Agrawal, S.R., An Indian customer surrounding 7P[U+05F3]s of service marketing, In: Journal of Retailing and Consumer Services, 2015, 22, 85-95

[21] Shukor, Ah.F.A., The Relationship Between Service Marketing Mix, Service Quality, Service Value and Customer Satisfaction in Doctor of Business Administration, 2016

[22] Champatong, S., Visitors'Attitude towards the Service Marketing Mix and Frequency of Visits to Bangpu Recreation Centre, In: International Journal of Social, Management, Economics and Business Engineering, 2014, 8, 6, 1996-1999

[23] Somocor, M., Marketing Mix and Service Quality (Servqual) Attributes As Determinants of Customer Satisfaction, In: International Journal of Contemporary Applied Researches, 2017, 4, 6, 134-187

[24] Aras, M., Syam, H., Akib, H., Haris, H., The Effect of Service Marketing Mix on Consumer Decision Making, In: The 1st International Conference on Education, Science, Art and Technology (the 1st ICESAT) Universitas Negeri Makassar, 22-23 July 2017, 108-112

[25] Hiransomboon, K., Marketing Mix Affecting Accommodation Service Buying Decisions of Backpacker Tourist Traveling at Inner Rattanakosin Island in Bangkok, Thailand, In: Procedia Economics and Finance, 2012, 3, 276-283, https://doi.org/10.1016/S2212-5671(12)00152-9

[26] Thamrin, H.M., The Role of Service Marketing Mix and Ship Service Quality towards Perceived Value and Its Impact to Ship Passenger's Satisfaction In Indonesia, In: Global Journal of Management and Business Research, 2012, 12, 3

[27] Octavia, A., The Influence of Service Marketing Mix and Service Quality on Students' Satisfaction In Jambi University, Indonesia, In: International journal of Economics, commerce and Management, 2017, V, 6, 398-414

[28] Alipour, M., Darabi, E., The Role Of Service Marketing Mix And Its Impact On Marketing Audit In Engineering and Technical Service Corporations, In: Global Journal of Management and Business Research, 2011, 11, 6

[29] Jalil, M.N., Customer Information Driven After Sales Service Management: Lessons from Spare Parts Logistics, Erasmus Research Institute of Management (ERIM), 2011

[30] Saccani, N., Johansson, P., Perona, M., Configuring the after-sales service supply chain: A multiple case study, In: International Journal of Production Economics, 2007, 110, 1-2, 52-69

[31] Zhou, Y., Dynamic pricing model of monopolistic manufacture based on the after-sale service, In: Computer Modeling \& New Technologies, 2014, 18, 6, 233-239

[32] Barrett, P., Structural equation modelling: Adjudging model fit, In: Personality and Individual differences, 2007, 42, 5, 815-824

[33] Hennig-Thurau, T., Customer orientation of service employees: Its impact on customer satisfaction, commitment, and retention, In: International Journal of Service Industry Management, 2004, 15, 5, 460-478

[34] Shareef, M.A., Kumar, U., Kumar, V., Role of different electronic-commerce (EC) quality factors on purchase decision: a developing country perspective, In: Journal of Electronic Commerce Research, 2008, 9, 2, 92-113

[35] Ling, A.P.A., The impact of marketing mix on customer satisfaction: A case study deriving consensus rankings from benchmarking, Master's thesis, 2007 
[36] Yoo, B., Donthu, N., Lee, S., An examination of selected marketing mix elements and brand equity, In: Journal of the Academy of Marketing Science, 2000, 28, 2, 195-211

[37] Sarstedt, M., Ringle, C.M., Hair, J.F., Partial Least Squares Structural Equation Modeling, 2017, https://doi.org/10.1007/978-3-319-05542-8

[38] Henseler, J., Ringle, C.M., Sarstedt, M., A new criterion for assessing discriminant validity in variance-based structural equation modeling, In: Journal of the Academy of Marketing Science, 2015, 115-135, https://doi.org/10.1007/s11747-014-0403-8

[39] Urbach, N., Ahlemann, F., Structural equation modeling in information systems research using partial least squares, In: Journal of Information technology theory and application, 2010, 11, 2, 5-40

[40] Hair Jr. J., Sarstedt, M., Hopkins, L., Kuppelwieser, V., Partial least squares structural equation modeling (PLS-SEM) An emerging tool in business research, In: European Business Review, 2014, 26, 2, 106-121

[41] Fornell, C., Larcker, D.F., Structural equation models with unobservable variables and measurement error: Algebra and statistics, 1981

[42] Wahab, N.A., Faizah, L., Hassan, A., The Influence of Marketing Mix and Customer Satisfaction on Customer Loyalty among Hijab Consumers, 2013

[43] Sudari, S.A., Tarofder, A.K., Khatibi, A., Tham, J., Measuring the critical effect of marketing mix on customer loyalty through customer satisfaction in food and beverage products, In: Management Science Letters, 2019, 9, 5, 1385-1396, https://doi.org/10.5267/j.msl.2019.5.012

\footnotetext{
Authors:

BESTOON OTHMAN ${ }^{1,2,3}$, HE WEIJUN ${ }^{1}$, ZHENGWEI HUANG ${ }^{1}$, WIRYA NAJM RASHID ${ }^{4,5}$, JING XI ${ }^{6}$, FANG YUAN ${ }^{1}$

${ }^{1}$ College of Economics and Management, China Three Gorges University, 443000 Yichang, China

${ }^{2}$ Department of Business Administration, Koya Technical Institute, Erbil Polytechnic University, Erbil, Iraq

${ }^{3}$ Scientific Research and Development Center, Nawroz University, Kurdistan Regional, Iraq

${ }^{4}$ Marketing Department, College of Administration and Economics, University of Sulaimani, Iraq

${ }^{5}$ Faculty of Administrative and Financial Sciences, Cihan of University 46001, Sulaimani/Kurdistan, Iraq

${ }^{6}$ College of International Communications, College of Foreign Languages, China Three Gorges University, China

\section{Corresponding author:}

JING XI

e-mail: geanxi@ctgu.edu.cn
} 